New Zealand journal of industrial relations, 1987, 12, 107-112

\title{
The applicability of the common law in an industrial relations context (with special reference to industrial action): a comment
}

\author{
Martin Vranken*
}

This paper reflects on the uneasy relationship that exists in New Zealand between common law and industrial law. A parallel is drawn with the move of labour law away from the general principles of the civil law in Continental Western Europe. It is argued that, especially in the context of ind ustrial action, the Labour Relations Act 1987 missed out on a unique chance to assert fully the social autonomy of New Zealand labour law.

\section{Introduction}

The Government's Green Paper (NZ Government, 1985) on industrial relations states that New Zealand legislation considerably restricts the freedom of strike and lockout. ${ }^{1}$ Also, as the discussion document points out, it is possible for a trade union that engages in some forms of industrial action to find itself defending a common law action for damages or injunction (Green Paper, vol. 2, p. 274). How very real this latter possibility is has recently been made apparent. The extensive media coverage of such cases as Ford and Tip Top ${ }^{2}$ has indeed served as a reminder that the legal regulation of industrial relations in this country is still subject to the common law as well as statutory law.

The purpose of this short essay is to comment on the use of common law action with respect to industrial action. It will be argued that, while the usefulness of statutory restrictions on the freedom to strike can and has already been questioned (e.g. Woods, 1979, p. 17ff; Geare 1982). similar objections can be raised as regards the appropriateness of common law limitations on the freedom of industrial action. Further and more fundamentally, it is submitted that the common law as such is inappropriate in dealing with industrial action in that it risks jeopardising the very concept of the social autonomy of industrial law. The relationship between common law and industrial law in this repsect is an uneasy one and is comparable to the (by and large) successful move of labour law away from the general principles of the civil law in Continental Western Europe. It is therefore to be regretted that the newly enacted Labour Relations Act 1987, in transferring jurisdiction in certain common law actions and as related to

* Lecturer, Industrial Relations Centre, Victoria University of Wellington. I would like to thank Professor Kevin Hince for the various discussions I have had with him in the course of the preparation of this article.

1 New Zealand Government(1985) Industrial Relations: A Framework for Review; Wellington. Government Printer (Vol 2, p. 275), hereafter referred to as the Green Paper.

2 On 23 March 1987, the High Court at Auckland ordered the Northern Storepersons and Packers Union to pay the Ford Motor Co damages of $\$ 1.66$ million in a case arising from a strike at the company's Wiri assembly plant last September. The union, apparently unaware that legal action had been taken, was not represented in Court and was subsequently successful in its move to have the judgment set aside. The union was given 30 days to file a statement of defence (CP1140/86. unreported). Meanwhile, however, Tip Top Ice Cream Co Ltd, is suing the Clerical Workers' Union for about $\$ 900000$ in damages over loss of profits and sales during a three-week strike last November. For a list of other pending damages claims arising out of work stoppages. see H Roth (1987). 
industrial action from the High Court to the Labour Court, limits itself to a basically cosmetic change.

Industrial action: statutory vis-a-vis common law restrictions

Until recently, the main piece of legislation curbing industrial action was the Industrial Relations Act 1973. However, the practical usefulness of the statutory restrictions it imposed on strikes and lockouts has been questioned in the past (Woods 1979; Geare 1982). The criticism has adequately been summarised in the Green Paper where it is pointed out that "in a system designed to achieve industrial harmony through negotiated settlement of disputes, iron-rod enforcement may be considered to be counter-productive" (Green Paper, vol. 2, p. 276). Thus, even though a (relatively high) number of strikes and lockouts were illegal under previous industrial legislation, the statutory restrictions were seldom enforced.

The new Labour Relations Act aims at introducing legislation which is both relevant and (hopefully) useful by clarifying the distinction between lawful and unlawful industrial action. The new Act does so, for the first time ever, by explicitly stating that there is a right to strike or lockout regarding interest disputes. While this statutory right is not without restrictions ${ }^{3}$, the Labour Relations Act 1987 thus broadens the overall lawfulness of industrial action in relation to disputes of interest (s 233 Labour Relations Act). Also, the statutory penalties on strikes and lockouts are discontinued (s 230(d) Labour Relations Act). Henceforth, the legal remedies for unlawful industrial action are an order for compliance or, alternatively, an injunction and/or damages based on an existing (at common law) civil action in tort (s 230(e) Labour Relations Act).

\section{Statutory remedy: order for compliance}

The statutory remedy of an order for compliance is to be seen as a court order for compliance with the Act or, more importantly, with the collective instrument that is binding on the litigating parties (Labour Relations Bill, Explanatory Note, pp. VI and VII). As such, it is fully consistent with the philosophy behind the new legislation. It is indeed believed that a basic lack of freedom on behalf of the collective parties to regulate their own relationship (and thus, to assume responsibility for their own behaviour and actions) accounts, at least in part, for the current malfunctioning of the industrial relations system. Thus it is assumed that a reduction of government intervention may be beneficial to the overall functioning of the system. Areas of reduced involvement by the State include both the scope of collective bargaining (Labour Relations Act. part VII) and also, of direct relevance for the purposes of this discussion, enforcement and administration of collective agreements (Labour Relations Act, part VIII).

Briefly, the collective parties are actively encouraged to set up their own machinery to govern their relationship during the currency of the collective instrument they have entered into. The effectiveness of that machinery in allowing for the peaceful settlement of potential disputes is the primary responsibility of the parties themselves (s 186(e) Labour Relations Act). It is only when one of the parties fails to abide by the contractual rules it itself helped to establish, that outside assistance can be invoked through the application for a compliance order (s 186(f) Labour Relations Act; compare s 48 (2)(d) of the Industrial Relations Act 1973).

3 The main statutory restriction undoubtedly is what can be referred to as the 60-days limit. Section 233 (1)(a) stipulates indeed that, if the strike or lockout relates to a matter that is the subject of a dispute of interest created with intent to procure an award or agreement in substitution for an award or agreement, the date of expiry of the latter award or agreement may be not more than 60 days after the date of the commencement of the strike or lockout. Moreover. an otherwise lawful strike or lockout shall be unlawful if the requirements as to notice have not been complied with: s 234(3).

4 About the use of assumptions in the Government's Green Paper on industrial relations. see $M$ Vranken (1986).

5 If the contracting parties do not stipulate their own procedure for the peaceful settlement of (rights) disputes, the clauses set out in the Sixth Schedule to the Act apply. The same is true if the contractual procedure is inconsistent with the statutory procedure: s 187 Labour Relations Act. 


\section{Common law restrictions: injunction and damages}

The common law remedies for industrial action are usually based on an economic tort having been committed. Economic torts are wrongful acts resulting in financial loss to another party. They are not simply limited to breach of statute. Under the new Labour Relations Act (s 242 ) the Labour Court is given exclusive jurisdiction with respect to the torts of conspiracy, intimidation, inducement of breach of contract, and unlawful interference with trade, business or employment. The jurisdiction conferred on the Labour Court for civil action in relation to strikes and lockouts shall be exercised by a judge alone and section 296 relating to urgency applies. $^{6}$

The 2 main remedies at common law are an injunction and damages. The Green Paper holds that (interlocutory) injunctions are the most frequently sought common law remedies because of the immediacy of industrial disputes. The usefulness of damages, so it can be inferred, is limited in that these apply only ex post: the primary concern of the other party (most commonly the employer) is for the industrial disruption to be discontinued so as to ensure that no further suffering or damage will follow. Hence, the general preference for injunctions over the damages remedy appears to be self-evident. Also, once an injunction has been issued, if it is subsequently not abided by, the defendant is likely to be held in contempt of court (Green Paper. vol. 2, pp $274 \mathrm{ff}$ ). The jurisdiction of the Labour Court in relation to injunctions is specifically provided for in section 243 of the Act.

However, as the recent cases have amply demonstrated, damages can be a most powerful remedy too. Especially where the amount awarded is substantial, its deterrent effect as to future industrial action by either the same or different parties ought not to be underestimated. Moreover, whereas injunctions may only render one particular industrial action ineffective. the damages remedy potentially puts the union out of business altogether. The seizure of union assets that may subsequently follow an award of damages, is likely to produce the very result labelled by Roth (in the context of union deregistration) as "legalised theft" (1986, p 21). And, of course, since damages are usually awarded some time after the underlying dispute has come to an end, its shock effect may prove to be particularly unpleasant to say the least. The knowledge that the union's funds will get a boost due to the increased minimum union membership requirement in the Act (s 6(2) Labour Relations Act) is then but of little comfort to a union having to face legal action at common law.

\section{Current policies regarding the autonomy of industrial law}

The Government's Green Paper, when considering the issue of legal restrictions on industrial action, also addressed the question as to the appropriateness of common law remedies.

Two possible alternatives to the current situation were identified. A first option would imply the complete removal of common law actions from the industrial scene. The second one is less radical in that it would simply involve putting restrictions on their use. The new Labour Relations Act indirectly identifies the latter option as being deemed the most viable one. By limiting the number of instances of illegal strike action, common law cases will arguably become more difficult to pursue. Also, by transferring jurisdiction from the High Court to the Labour Court, the likelihood ought to increase that the wider social aspects of industrial relations and, more precisely, the special industrial dispute resolution procedures will be taken into account.

It needs to be stressed, however, as has already been indicated above, that the jurisdiction of the Labour Court in torts is to be exercised by a judge alone. No advantage can therefore be taken of the unique tripartite composition of the Court as it used to apply to industrial disputes in general. Also, the criteria for appointment of judges to the Labour Court contain no explicit

Section 296 is new. It provides that. in 5 specifically enumerated circumstances. any party to the proceedings can apply to the Court to accord urgency to the hearing of those proceedings. A judge of the Labour Court shall then consider that application and may. "if satisfied that it is necessary and just to do so", order that the proceedings be heard by the Court "as soon as practicable".

Unlike the previous situation under the Industrial Relations Act 1973, the jurisdiction of the Labour Court shall be exercised, as a general rule, by a judge sitting alone. The only specific exceptions to this general rule, as provided for in the Labour Relations Act 1987. are demarcation disputes and personal grievances. See s 295 (1) Labour Relations Act. 
reference to the requirement of any special skills or expertise in industrial relations nor even, more narrowly, in industrial law (s 288 Labour Relations Act). Furthermore, it is to be noted that the exclusive jurisdiction of the Labour Court is limited to 4 specifically enumerated economic torts. There is nothing to prevent the High Court from developing its own (newly to be established) economic torts in relation to strikes and lockouts. Even though it has been held by Mulholland (1985) to be a debatable question as to whether Courts are nowadays still able to create new torts ${ }^{\circ}$, any such newly established economic torts would unquestionably come within the jurisdiction of the High Court. And, of course, the Labour Court is not given exclusive jurisdiction with respect to more general (non-economic) torts, all of which may also play a role in the overall context of industrial action. Wrongful acts such as envisaged by, for instance, the torts of negligence, trespass or nuisance all come within this category. Especially crucial, however, is that, whenever the jurisdiction of the Labour Court in relation to torts (s 242) is invoked, the determinations by the Court must be based on strictly legal principles only. As it is also the case with respect to injunctions (s 243) and applications for review (s 280), the jurisdiction of the Court to decide "as in equity and good conscience it thinks fit" does not apply (s 279(4) Labour Relations Act).

One is left to wonder why what was identified as the first option, namely the removal, as such, of common law remedies from the industrial scene, was dismissed so readily. The Green Paper itself acknowledges that a case can indeed be made for granting complete immunity to industrial action from common law action. The justification given for its rejection is however that, as economic torts are "... relevant in contexts other than the industrial one, it is questionable as to whether actions carried out in the industrial sphere should be treated differently than if they were performed by any other individual or group" (Green Paper, vol. 2, p 277 , no. 72). As it will be argued below, such justification is highly unsatisfactory in that it amounts to a direct negation of the social autonomy of industrial law.

Ever since the enactment of the first Industrial Conciliation and Arbitration Act in 1894 , the legal regulation of labour-management relations has increasingly proceeded in such a way as to recognise the deficiencies in applying strict principles of common law. In fact the very principle of adopting special legislation to deal with the relationship between the parties and the official designation of (registered) unions as the collective representatives of individual workers and employers are by themselves proof of the recognition that special priorities and needs operate on the industrial scene. Hence, the role of the common law has become marginal over time (Szakats, 1981, p 12) both in the area of individual and collective labour law. A fairly recent illustration of this acknowledged need for special techniques, procedures, principles and notions is the statutory concept of unjustifiable dismissal as distinct from wrongful dismissal at common law. The latest indication of this move towards autonomy is arguably provided by the title itself of the new legislation as being a "Labour relations" Act rather than an "Industrial relations" Act. The more traditional term of industrial relations, prevalent in New Zealand, refers readily to such notions as industry or commerce and, thus, it has economic connotations. Labour relations, on the other hand, is a term which is commonly used in Europe and has the particular advantage of stressing the presence of a uniquely social component in the labour-management relationship. Thus it refers to an area of the law which is distinct from other branches of the law regulating economic activity, such as company law or commercial law but also the law of contracts and the law of torts.

By explicitly confirming that a common law cause of action (no matter how limited this may be under the new Act) still exists, and, moreover, that common law proceedings can now be started in the Labour Court, the legislature appears to turn back the clock 100 years.

\section{The civil law experience}

The relationship between common law and industrial/labour law has undoubtedly always been an uneasy one. The New Zealand situation is by no means unique in this respect. Even in the so-called civil law systems of Western Europe a comparable (and likewise uneasy) relationship between the principles of the civil code and specific labour legislation has persisted for many years and, at least in some instances, for example Switzerland, still continues. However. in Europe as well, the general evolution has been one of gradual recognition of the autonomy of 
labour law by the legislature and, most importantly, by the social partners themselves. This autonomy of labour law on the Continent was the result of an evolutionary process, both in quantitative and qualitative terms.

Quantitatively, the autonomy of labour law has been brought about by the ever increasing amount of special labour legislation and number of collective agreements, especially since World War II. Even more noteworthy is the qualitative change that accompanied the steadily growing body of labour law rules. As it has been argued by Blanpain, a leading European scholar in (comparative) labour law, the emphasis in labour law is on solidarity rather than on individualism. Hence, it would be wrong to interpret the rules of labour law in terms of contractual freedom and (fictional) equality of the parties, both of which are so basic to civil law. Instead, a proper interpretation of the labour law rules must take place in function of the modern values that form the core of labour law, in casu job security and guaranteed income (Blanpain, 1983, pp. 42 ff).

Briefly, even though labour law in Europe initially tended to be viewed as part and parcel of the general civil law as it indeed grew up under the aegis of individual contract law, the plea for its autonomy can be understood if seen as a reaction against the laissez-faire principles of the civil code. The practical result is that, even though civil law continues to have residual importance, its application in labour matters is to be rejected whenever it risks producing results which go against the very ideas and principles labour law stands for.

An illustration as to how the tension between civil law and labour law can be (and indeed has been) resolved in favour of the autonomy of labour law is provided in the French Labour Code. In France the right to strike is expressly guaranteed by the Constitution. Yet, French unions can undeniably be held liable for losses arising from industrial action ever since the Jaures case which dates from the turn of the last century. The general legal basis for a civil action in tort is article 1382 of the Civil Code. As has been observed by Forde, although the question of civil liability for strike action was of little practical importance for many years in France as well, this is no longer the case. Recently, there has been an upsurge in the number of damage claims by French employers (and by non-strikers) against strikers, union representatives and trade unions alike (Forde, 1985). However, the employer's ability to recover damages is specifically limited by Article L. $411-12$ of the Labour Code. Article L.411 - 12 stipulates that the real and personal property a union needs for its meetings, training programmes and libraries cannot be seized. Thus, an employer's suit for damages will not be allowed to force the union into bankruptcy (M Forde, p. 454).

The limited tort liability of French unions is somewhat comparable to the current situation in Britain under the Employment Act 1982. In Britain, the Thatcher Administration removed the immunity in tort traditionally enjoyed by unions. However, the 1982 Act places limits on the maximum amount of tort damages that can be awarded. The limits are related to the size of the membership of the union, the maximum amount of damages being $£ 250000$ (i.e. some $\$ 750000$ ) in the case of a union with 100000 or more members (Employment Act 1982, s 16).

\section{Conclusion}

As civil law on the Continent largely performs the same functions as the common law in New Zealand, and as collective representation of the workers is among the central pillars of labour law in New Zealand as well as in Europe, any application of the common law which would negate such a crucial principal is necessarily inappropriate. The admissibility of common law action in respect of industrial action risks upsetting this principle of collective representation. It is to be regretted that what once was announced as a most fundamental review of industrial legislation in this country appears to have missed out on a unique chance to assert fully the social autonomy of New Zealand labour law.

\section{References}

Blanpain. R (1983) Schets van het belgisch arbeidsrecht Brugge. Die Keure.

Forde, M(1985) Liability in damages for strikes: A French counter-revolution American journal of comparative law 133: 447 - 465 . 


\section{Martin Vranken}

Geare. A J (1982) Penalties for strike action New Zealand law journal 361 - 363.

Mulholland, R D (1985) Introduction to the New Zealand legal system Wellington, Butterworths.

New Zealand Government (1985) Industrial relations: A framework for review 2 volumes, Wellington. Government Printer.

Roth. H (1986) Legalised theft by deregistration New Zealand journal of industrial relations 11(1):21-26.

Roth. H (1987) Industrial summary: March - April Industrial law bulletin (3):35.

Szakats. A (1981) Introduction to the law of employment Wellington, Butterworths.

Vranken, M (1986) Symposium: Green Paper on industrial relations - comment New Zealand journal of industrial relations 11(1):5-7.

Woods, N S (1979) Troubled heritage: The main stream of developments in private sector industrial relations in New Zealand Wellington, Industrial Relations Centre.

\section{List of Cases}

Ford Motor Company of New Zealand Limited v Northern Industrial District and Hawke's Bay Province Storepersons and Packers, etc, I.U.W. (1987) 4 Ind Law Bull 41 (unreported).

Affaire Jaurès (1897) 1 Dalloz 537. 